\title{
Local People Perception on Biodiversity Change In Lower Mustang
}

\author{
Sambhu Paudel ${ }^{1}$ and Trishna Rayamajhi ${ }^{2}$ \\ Corresponding Author: Trishna Rayamajhi \\ E-mail: trishna_rayamajhi@yahoo.com
}

\begin{abstract}
Local people response was obtained on biodiversity change in lower Mustang relying on social survey and from various data sources for natural assets. The main focus was centralized on the change in avifaunal and mammalian diversity and the effect of environmental change on agricultural/livestock forest as well as on grazing land. The change was detected on wildlife movement, livestock depredation, forest stock, palatable species and birds. Climate change is the key issue in conserving biodiversity and linking its goal in livelihood. Change in livelihood pattern seems more adverse factor for community development as urbanization is prevalent. Animals and birds solely dependent in the nutshell area are at increasing rate but transition (forest and agriculture) species are decreasing.
\end{abstract}

Key Words: Biodiversity change, Avifaunal and mammalian diversity, Climate change

\section{Introduction}

Lying between Paleoarctic and oriental realms, Nepal owes a sharp change in altitude and is situated between six floristic zones. Nepal is a home to 963 species of birds and 181 species of mammals (NBS, 2006). Recognizing the importance of conservation of flora and fauna, Nepal has declared almost $23.23 \%$ of the total land covers into various kinds of protected areas suitable to particular locality and so globally appreciated as one of the leading country in conservation (DNPWC, 2011)

Covering the area of 7,269 km², Annapurna Conservation Area Project (ACAP) launched at 1986, is a treasure house for 1226 plant species, 38 orchids species, 9 rhododendron species, 101 mammals, 474 birds, 39 reptiles and 22 amphibians species. Rare and endangered species like Snow leopard, Musk deer, Tibetan argali, Impeyan pheasant and Tragopan pheasant are harbored by ACAP. ACAP is regarded as one of the most biologically diverse reserves on the earth (UNEP, 1995). ACAP has a huge altitudinal range spanning from 790 to $8091 \mathrm{~m}$. It has a great range of rainfall with some of the driest regions in Nepal in the Trans-Himalayan zone and some of the wettest regions south of Annapurna in the Modi Khola valley (NTNC, 2008).

1 Assistant Lecture, Kathmandu Forestry College

2 Student, Kathmandu Forestry College 
Within the area of ACAP, Mustang is the most popular destination receiving almost $30 \%$ visitors trekking in ACAP (NTNC, 2008). Lower Mustang covers nine VDC which extend from Lete to Jhong and all of above lies in lower Kali Gandaki river basin. Joshi et.al.(1994) analyzed and emphasized that Annapurna Himalayan Range provides a massif geographical barrier in terms of faunal distribution whereas river gorges of Marsyangdi, Kaligandaki are amiable migration route for faunal species. The conservation area has been divided into 4 zoogeographic zones based on climatic, geotropic and broad vegetation characteristics.

These impact factors entail regular monitoring and listing of wild animals and birds to seen trend and status to take appropriate conservation and management measures assessing the existing community needs.

Thus this study proposes to assess the current existing scenario of ecological community in lower Mustang by understanding people's perception.

\section{Methedology}

\section{Data collection techniques}

\section{Teamwork and Questionnaire survey}

Team work was initiated with group discussions among members, checklist development and questionnaires preparation. Checklist covered climate change, change in forest, change in wild animals and birds, occupation and human life conflicts. Prepared questionnaire survey design was presented and approved by Jomsom UCO staff and was conducted by judgment sampling making altitudinal line transect. Key informant interview was carried targeting local aged herders, farmers and tourist guides.

\section{Field observation}

Firstly, direct field observation was carried out for 12 days in lower Kaligandaki, also a separate forest patrolling was carried out in each VDC.

Secondly, an especial forest patrolling mission was held out on the way (to Dolpa) for three days. During this mission, team stayed in cave for exploring and digging out of wildlife and vegetation status intimately at that area.

\section{Group discussion}

Two group discussions were carried out prior to survey in Kobang and Marpha VDC which finally showed that average individual response was similar to groups' responses. 


\section{Results and Discussions}

Socioeconomic status

Table 1: A brief socioeconomic status of respondent communities

\begin{tabular}{|l|c|c|c|c|c|}
\hline \multirow{2}{*}{ Gender } & \multirow{2}{*}{ Percentage } & \multicolumn{3}{|c|}{ Occupation } & \multirow{2}{*}{ Total } \\
\cline { 3 - 5 } & & Farmer & Tourism & Both & \\
\hline Male & 73.3 & 173 & 17 & 5 & 195 \\
\hline \multirow{2}{*}{ Female } & 26.7 & 62 & 9 & & 71 \\
\cline { 2 - 6 } & & & & & 266 \\
\hline
\end{tabular}

Status of Natural capitals over 20 years

Relying on social survey and from various data sources, it can be concluded that livestock depredation has increased very high $(n=211)$ whereas the palatable species has decreased $(n=131)$. Data analysis shows that the frequency of birds and forest stock has increased comparatively.

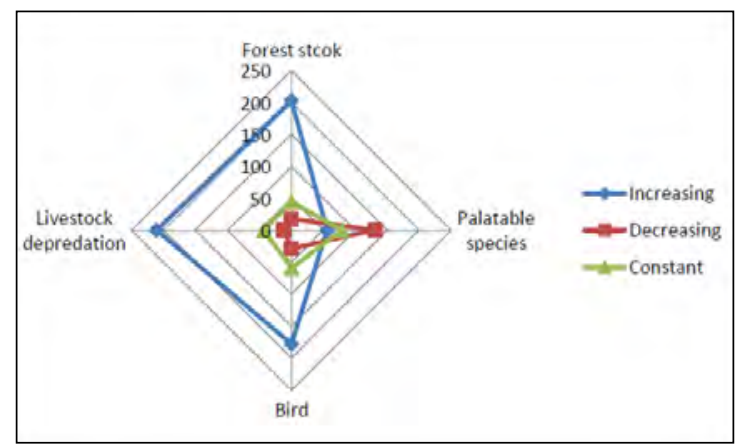

Figure 1: Status of Natural capitals over 20 years

\section{Climate Change and Agriculture Production}

This survey shows that the production of agriculture crops $(n=187)$ has decreased and at the same time snowfall amount $(n=261)$ rate has also been decreased. Overall all the variables taken for the consideration of climate change and agriproduction were in declining trend.

For further exploration, people were asked and they responded that there was change in snowfall pattern in the study site. No new species were noticed as well as no disappearance of species was noticed in around 20 years. Regarding the use of chemical fertilizers, 8\% 
responded that they were still using chemical fertilizers, $12 \%$ were reducing the quantity of chemical fertilizers and 39\% weren’t using any.

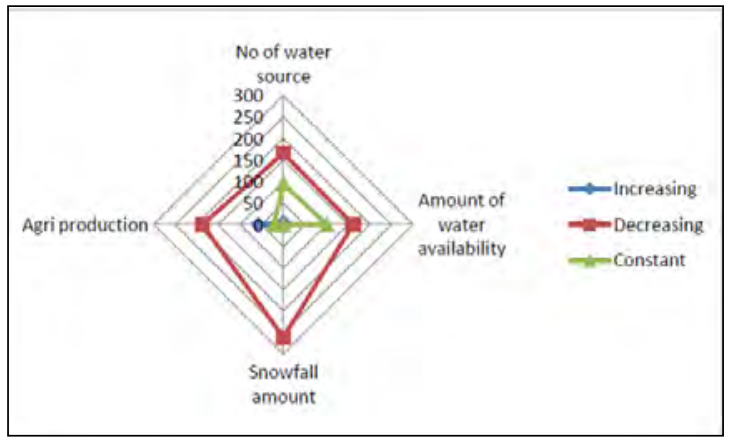

Figure 2: Climate Change and Agriculture Production

Trend of Wildlife Moment (over 20 yrs.)

Wildlife moment is also another key to assess the changeover biodiversity because of its depended over natural ecosystem and also reflects status of wildlife and habitat indirectly. To understand people perception on wildlife moment, six variables were developed. In the process of understanding the people's perception on wildlife, it revealed that transitional zone between agriculture and forest is the most frequently used site for wildlife moment. It also revealed that the least used site was home yard.

Impact of Road development on Biodiversity conservation

Impact of road on overall natural heritage of lower Mustang is assessed using non parametric test.

\begin{tabular}{|l|c|c|c|c|c|c|}
\hline \multirow{2}{*}{ Occupation } & \multicolumn{5}{|c|}{ Response } & \\
\cline { 2 - 7 } & Positive & Negative & No idea & As it is & Dual & Total \\
\hline Farmer & 153 & 10 & 7 & 6 & 15 & 191 \\
\hline Tourism & 22 & 5 & 5 & 5 & 5 & 42 \\
\hline Both & 5 & 6 & 7 & 8 & 7 & 33 \\
\hline & & & & & & 266 \\
\hline
\end{tabular}

\section{Discussions}

There are clear indications from a number of high elevation climate records that the amplitude of temperature changes this century is greater than the observed global or hemispheric change (Beniston, 1996). Since mid 1970s, the average air temperature 
measured at 49 stations of the Himalayan region raised by $10 \mathrm{C}$ with higher elevation sites warming the most (Hasnain,2000) .This is twice as fast as $0.60 \mathrm{C}$ averages warming for the mid-latitudinal northern hemisphere over the same time period.(IPCC,2001).Most of the respondents remarked that decrease in production of agriculture land is due to shift in rainfall pattern and snowfall period which also led to widespread disruption of fresh water supply. Meteorological and climatic processes in mountain regions play key role in many environmental ecosystems. Research showed that evapotranspiration and evaporation were also distributed by +20 C and $40 \mathrm{C}$ monthly temperature rise (Fennessey, 1994).

Possibility of wider gaps in protected area management is one of the projected impacts of climate change in ecosystem management. The reduction in palatable species is a reason for wildlife forcing to enclave human settlement inducing conflicts. Urbanization is also one of the adverse impacts over agriculture production and abandonment. As consequences, there is no change on bird's diversity but movement in wildlife is increased. Use of chemical pesticides provided by VDC plays vital role to reduce avian diversity and chemical poisoning is inducing death of Snow Leopard. But surprisingly most of the farmers were able to detect adverse impact and were avoiding the use of chemical fertilizers since last year.

Road development was the issue of which the hotel enterprisers were against due to the possible reduction of economic transaction whereas the poor segments of society along the road tracks would be benefitted due to reduction of price of goods.

\section{Conclusion}

Over 20 years, there is no any significant change over natural resource and agriculture production. However some glimpse of indication in the field of climatic variable induces certain change in lower Mustang influencing water availability for agriculture production and other usage. Impact of climatic variability is compounded by chemicals fertilizers but its usage is in reduced level now. The wildlife moment is in the state of increasing whereas bird's vicinity of settlement is decreasing because of poisoning effect of agricultural pesticides. Urbanization and change in livelihood pattern seems more adversely responsible for land abandonment and reduction of agricultural goods.

Interesting moment is of rampant movement of wildlife in Kunjo and Lete , Kobang and Tukuche VDC. Increasing numbers of leopards create opportunities for further assessment of leopards' status in Kunjo VDC and migratory birds' status in Muktinath VDC of lower Mustang.

This reflects effectiveness of conservation measures carried out in Mustang but wildlife population increment is leading conflicts and indiscriminate use of chemical fertilizer is creating a possible threat. 


\section{References:}

Acharya R. 2004. Survey of the Cheer Pheasant in lower Kali Gandaki valley, Mustang, Nepal.Report Submitted to National Trust for Nature Conservation (NTNC), Annapurna Conservation Area Project (ACAP). Pp 39.

Agrawala S, Raksakulthai, V., Aalst, M., Larsen, P., Smith, J. and Reynolds, J. 2003. In Development and climate change in Nepal: focus on water resources and hydropower. Organisation for Economic Cooperation and Development, Paris, 4-8.

Bagoora, F.K. CHALLENGES OF CLIMATE CHANGE IN MOUNTAIN ECOSYSTEMS IN AFRICA. 2010 National Environment Management Authority (NEMA), P.O.Box 22255, Kampala Uganda

Beniston, M., Diaz, H.F and Bradley,R.S...... CLIMATIC CHANGEATHIGHELEVATION SITES: AN OVERVIEW. Institute of Geography, University of Fribourg, P'erolles, $\mathrm{CH}-1700$ Fribourg, Switzerland

Dahal, N. 2006. Implications of Climate Change on Biodiversity in Nepal: Some Observations and Opportunities. Paper presented at 23rd Warden Seminar November 2006 held in Pokhara, Nepal. National Trust for Nature Conservation, Kathmandu, Nepal.

DNPWC. 2004. Visitors to Nepal's Protected Areas, unpublished report (Kathmandu, Nepal: Department National Parks and Wildlife Conservation).

DNPWC. 2011. Protected Areas of Nepal. Department of National Parks and Wildlife Conservation (DNPWC), Kathmandu, Nepal.

Fennessey, N. M. and P. H. Kirshen. 1994. Evaporation and evapo-transpiration under climate change in New England.

Haiberli W. 1990. Glaciers and permafrost signals of 20th century warming. Annals of Glaciology 14, pp 99-101.

Hannah, L, and Salm, R. 2003: Protected Areas and Climate Change. In Hannah, L and Lovejoy, T.E. (Eds) Climate Change and Biodiversity: Synergistic Impacts. Advances in Applied Biodiversity Science No 4. Centre for Applied Biodiversity Science. Conservation International. Washington.

Hasnain, SI. 2000. Status of the Glacier Research in the HKH region. 2000, ICIMOD, Kathmandu, Nepal.

Inskipp, C. \& Inskipp, T. 2003. Bird conservation priorities of the Annapurna conservation area.Report to UNEP-WCM/King mahendra trust for nature conservation Annapurna conservation area project. 
IPCC. 2001. Climate Change: Impacts, Adaptation and Vulnerability, Contribution of Working Group II to the Third Assessment Report of the Intergovernmental Panel on Climate Change. Cambridge: Cambridge University Press.

IPCC. 2007. Summary for Policymakers, In Climate change 2007: impacts, adaptation and vulnerability. (eds.) Parry, M.L., Canziani, O.F., Palutikof, J.P., Linden, P.J., and Hanson, C.E. Contribution of Working Group II to the Fourth Assessment Report of the Intergovernmental Panel on Climate Change, Cambridge, Cambridge University Press: 1000p.

MCTCA. 2004. Annual Statistical Report 2004 (Kathmandu: Ministry of Culture, Tourism and Civil Aviation).

Mitche. RT. 1946. Effects of DDT spray on eggs and nestlings of birds. Journal of Wildlife Management, 10:192-194.

NBS. 2006. Nepal Biodiversity Strategy (NBS).

NTNC. 2008. Sustainable Development Plan, Mustang 2008-2013. National Trust for Nature Conservation (NTNC), Kathmandu, Nepal. Pp 102pp. Oerlemanns, J. 1994. Quantifying global warming from the retreat of glaciers. Science 264, 243-245.

Peters, RL. 1991. Consequences of global warming for biological diversity. In Wyman, R.L. (ed.) Global Climate Chalnge and Life on Earth. PP. 99-118. New York. Routledge, Chapman and Hall.

Shrestha, NM. 2005. Short Description of lovely Mammal, Pika, “The Prabhat Vol. 1, Pub. 12, Yr. 13, 2005”, Publication on Forestry and Literature, published by All Nepal National Free Students’ Union, IOF, Pokhara, Nepal.

Shrestha, NM. 2009. Temporal Change Detection of Potentially Dangerous Lumding Tsho Glacial Lake in Dudh-Koshi Basin. A Thesis paper submitted for partial fulfillment of Bachelor in Forestry Science, Institute of Forestry, Pokhara, Nepal.

UNEP. 1995. Global biological assessment. Cambridge University Press, Cambridge, UK. Weed, F.B. 1990. Monitoring global climate change: the case of greenhouse warming. Bulletin of the American Meteorological Society, 17, 1, pp 42-52.

WWF. 2005. An overview of glaciers, glacier retreat, and subsequent impacts in Nepal, India and China. World Wildlife Fund, Nepal Program. 